\title{
Business Innovation, Ethics, And Prosperity: The Primacy Of Microeconomics
}

\author{
Rock-Antoine Mehanna \\ Notre Dame University • Zouk Mosbeh, Lebanon \\ Youssef Yazbeck \\ Central Bank of Lebanon and \\ Saint Joseph University • Beirut, Lebanon
}

\section{Abstract}

This paper examines the role of "business innovation" and "business ethics" - two seemingly unrelated principles - in underpinning the disparities in economic prosperity across 107 countries over the period from 2003 to 2006. Unlike Porter, Ketels, and Delgado's (2007) statistical approach, which relies on partial correlations, this paper uses a multiple regression analysis within a general macro/microeconomic framework to examine business innovation strategies and ethics, while controlling for human capital, geography, and socio-cultural demographics. Additionally, this paper borrows from $\mathrm{Wu}(2005)$ to assess the interaction between business innovation strategies and business ethics. Econometric results indicate that business innovation and business ethics are both positively correlated with and needed to sustain economic prosperity. Additional results show that microeconomic variables have the primacy over macroeconomic ones. Relevant policy implications are discussed.

\section{Introduction}

The problem of creation of wealth has always been the in-focus of economic research. While the bulk of the literature emphasized the role of macroeconomic factors, the microeconomic foundations of economic prosperity escaped theoretical and empirical scrutiny. Building on Porter's $(1990,2007)$ approach to economic prosperity, the purpose of this paper is to empirically test the following: (1) The significant relationship of each of "business innovation" and "business ethics" (or corruption) - two seemingly unrelated principles - in underpinning the disparities in economic prosperity across a sample of 107 countries over the average period from 2003 to 2006; (2) the interaction between business innovation strategies and business ethics; and (3) the size and significant roles of macro- and microeconomic foundations in affecting economic prosperity.

The microeconomic approach to economic prosperity gained much importance with the growing pace of globalization. Globalization increases the uncertain- 
ties of macroeconomic policies and makes countries more vulnerable to the fluctuation of variables, such as exchange rates and commodity prices among others. In fact, Argentina failed to experience a sustainable path of growth because the improvement of the microeconomic environment was not in-line with the macroeconomic reforms that the government has undertaken (Ketels, 2006).

While the potential to create a competitive advantage at the corporate level lies in the development of innovative products and processes, including conducting innovation-driven business strategies, this paper suggests that corporate ethics, specifically corporate corruption should not be underestimated. Borrowing from Wu (2005), the tough enforcement of the Foreign Corrupt Practices Act may have forced U.S. companies to focus their attention on developing their long-term competitive advantage through implementing business innovation strategies leading them to be recognized as global leaders in their fields.

Unlike Porter's et al. (2007) statistical approach which relies on partial correlations, this paper employs a general micro/macroeconomic framework and uses a multiple regression to examine the effects of business innovation and business ethics (corruption) on economic prosperity as measured by the level of per capita gross domestic product (GDP). It controls for salient features of economic prosperity, including human capital (education), geography (latitude), and socio-cultural demographics (religious fractionalization). Using the standardized estimation of the independent variables, this paper assesses the magnitudes between microeconomic and macroeconomic environments and their impact on economic prosperity.

The rest of the paper is organized as follows. The second section reviews succinctly the related literature, while suggesting a synthetic theoretical diagram (Figure 1). The third section offers the specification of the model and the fourth section analyzes the econometric results. Finally, the fifth section concludes the study and provides some relevant policy implications.

\section{Literature Review}

\section{Business Innovation and Economic Prosperity}

The relationship between innovation and economic prosperity (or economic development) witnessed a surge in interest over the last decades. Contemporary innovation theories (i.e., New Growth Models and Evolutionary Theories) revived the seminal contribution of Schumpeter $(1934,1939,1943)$; innovation within large corporations explain the never ending and ever changing process of economic prosperity (Castellacci, 2007). New growth theories highlight the role of innovation while em- 
ploying a neoclassical typological thinking (see among others, Romer, 1986; Lucas, 1988; Grossman \& Helpman, 1990; Bresnahan \& Trajtenberg, 1995; Helpman, 1998).

Evolutionary theories like, for instance, the Neo-Schumpeterian Theory (see among others, Freeman, Clark, \& Soete, 1982; Perez, 1985; Freeman \& Louça, 2002), the Technology Gap Approach (see among others, Abramovitz, 1994; Chui, Levine, Murshed, \& Pearlman, 2002), the Nelson and Winter-like Evolutionary Theorizing (Nelson \& Winter, 2002), and the Innovation System Frameworks (Freeman, 1987; Porter 1990) consider that agents are heterogeneous and follow routines and habits of thoughts that are embodied in their minds and in the organization's production activities. These routines and habits are transmitted over a population and explain a stable inertial pattern of production over time. Innovation is shaped by the interaction between microeconomic actors and macroeconomic structures. It continuously counteracts this inertial pattern via novel learning processes and exploring activities. Such phenomena make evolution a never ending process. Without innovation, competition and selection between the heterogeneous firms reduce the initial heterogeneity and explain the convergence to a stable steady state.

Porter's approach to economic prosperity falls within the framework of the National Innovation System. Following Freeman (1987), a National Innovation System is a network of public and private institutions, whose activities and interactions initiate, modify, and diffuse new technologies. Porter (1990) and Porter et al. (2007) argue that differences in economic prosperity within countries depend on two areas that are inextricably intertwined: (1) the quality of the microeconomic business illustrated by the components of the Porter's Diamond (1990) (i.e., input conditions, context for firm strategy and rivalry, demand conditions, related and supporting industries); and (2) the quality of the sophistication with which domestic companies and foreign subsidiaries operating in a country compete. The holistic view of the process of economic prosperity does not neglect the pivotal role played by the population of heterogeneous firms in sustaining the evolutionary phenomena of competition and selection. Firms are agents of value creation. Value creation occurs via the introduction of innovative products and processes and the implementation of innovation driven business strategies that identify a firm's competitive advantage.

\section{Business/Corporate Ethics and Economic Prosperity}

In this paper the terms business ethics and corporate ethics are used interchangeably. The bulk of economic literature dealing with the syndrome of corporate ethics (corruption) underpinned the detrimental effects of corrupt government 
officials (Mauro, 1995, 1996; Treisman, 2000; Henisz, 2000; Smarzynka \& Wei, 2000; Méon \& Sekkat, 2005). Corruption reduces domestic and foreign investment. It amplifies the unofficial activity, lowers private sector employment, leads to a misallocation of public spending, exacerbates poverty and inequality, undermines the rule of law, and increases political instability.

Corporate corruption, a specific dimension of corporate ethics, escaped much scrutiny. It generates organizational and environmental deficiencies that undermine the competitiveness of firms and exhibit detrimental effects on economic prosperity.

Organizational deficiencies are a mere reflection of the principal-agent problem at the organization's level. Such a problem may represent a corporate threat (Coulomb, 1997). Corruption leads to a misallocation of resources and a deterrence of capacity building. A competent management who strategically allocates a company's limited resources is fundamental to boost a firm's growth potential. However, corruption may lead to the concealment of management's real contribution to the increase of the economic value of firms ( $\mathrm{Wu}, 2005)$. Accordingly, corrupt practices (within an organization or between an organization and its environment) may be substitutable for innovation-driven organizational skills. Despite several critics that have been addressed to the Foreign Corrupt Practices Act for placing American companies in a competitive disadvantage in many emerging markets, it seems that toughness on bribery might have forced the U.S. companies to focus their attention on developing their innovative capacity (Wu, 2005).

Furthermore, corporate corruption mirrors dishonesty and untrustworthiness and destroys business networks. Building a long-term competitive advantage requires to maintain long-term relationships with suppliers, distributors, consumers, and other agents involved in a value chain.

Environmental deficiencies involve the socio-economic impact of corporate corruption. Assume that two firms compete for a public contract and the pay-off pattern is represented as follows: (1) if none of the two firms pays a bribe, both gain four monetary units; (2) if both firms make a bribe payment, they gain one monetary unit; and (3) one firm gains an unfair advantage (i.e., three monetary units) over the other firm if the latter does not pay a bribe (no monetary gain). Theoretically, such a game has two equilibria: (1) bribe-bribe; or (2) do not bribe-do not bribe. Rationality implies that the first equilibrium is the most probable. Such equilibrium is not but the worst scenario to the collectivity.

Additionally, Hellmann and Schankerman (2000), Kaufmann and Kraay (2002), and others argue that firms may have vested interest in a socially inefficient statusquo. Hellmann and Schankerman show that captor firms benefit from their ties with 
government officials to impose high regulatory burdens on their competitors. Such a regulatory burden sustains their power and leads to a "monopolistic" social deficiency.

\section{Figure 1}

The Macroeconomic-Microeconomic Framework; Underlining the Role of Business Innovation and Business Ethics

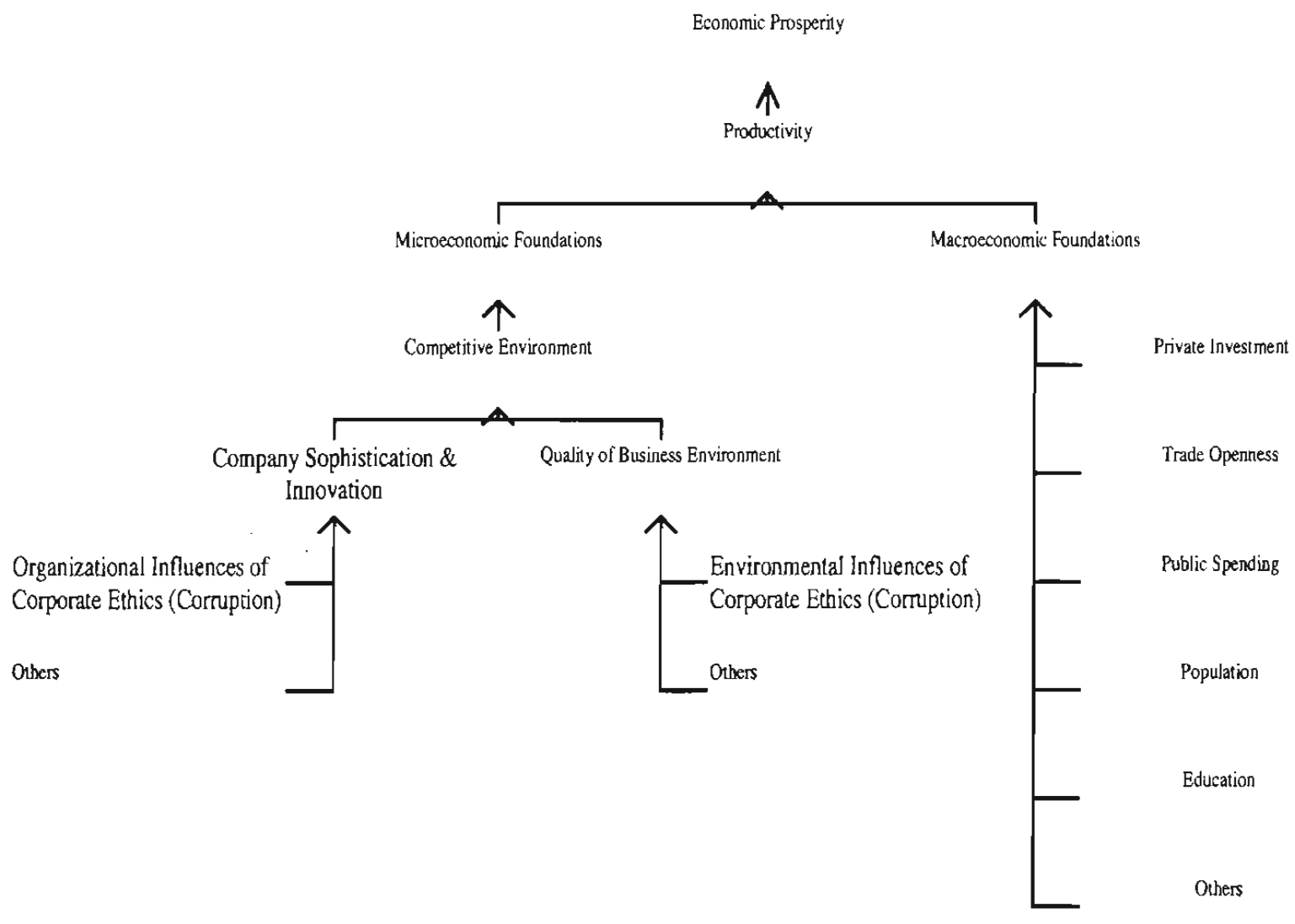

\section{Methodology}

This paper estimates the following functions on a sample of 107 countries using a multiple regression analysis following the White's procedure (1980) over the average period from 2003 to 2006 :

$\log G_{\text {GDP }}=f\left(I_{i} ;\right.$ OPENNESS $_{i} ;$ EDU $_{i} ;$ IBS $_{i} ;$ LATITUDE $_{i} ;$
FRACTIONALIZATION $)$

$\log G D P_{c i}=f\left(I_{i} ;\right.$ OPENNESS $_{i} ;$ EDU $_{i} ;$ ETHICS $_{i} ;$ LATITUDE $_{i} ;$ FRACTIONALIZATION)

Log GDP ${ }_{c i}=f\left(\left(_{i} ;\right.\right.$ OPENNESS $_{i} ;$ EDU $_{i} ;\left(I B S^{*} E T H I C S\right) ;$ LATITUDE $_{i} ;$ FRACTIONALIZATION,) 
where $i$ is a subscript that represents the country and the level of per capita GDP is used as a proxy for economic prosperity. The rational for relying on the level of per capita GDP is sustained by the following: (1) there exists a common agreement among economists that the current dispersion of per capita GDP levels among countries reflect differences in their long-term growth (Kaufmann \& Kraay, 2002); (2) differences in economic growth rates across countries may be transitory; and (3) differences in economic policies are empirically associated with differences in levels rather than differences in economic growth rates (see among others, Hall \& Jones, 1999).

The quality of ethics is represented by the following: (1) "ethical behavior of firms," a broad indicator which represents the quality of interactions between a firm and its environment (i.e., private organizations or public ones); and (2) "illegal corruption," an indicator that specifically assesses the level of corporate corruption within a country (i.e., private-public corruption).

Variables employed as proxies for business innovation and business ethics are not included in the same regression to avoid multicollinearity problems. The interaction between business ethics and business innovation is not but the product of the innovation and business sophistication score (IBS) and index reflecting the ethical behavior of firms. Table 1 provides a synthetic description of each of all variables employed to estimate the above functions.

Relying on both the theoretical framework previously described as well as on Porter's et al. (2007) empirical results, this paper hypothesizes the following: (1) the degree of business innovation and business sophistication should have a positive and significant impact on economic prosperity; (2) business ethics, whether measured broadly or specifically, is a precondition to sustainable prosperity and should not be underestimated; (3) business innovation and business ethics interact so that improvement in both indicators is needed to sustain economic prosperity; and (4) the role of microeconomic foundations is as instrumental as macroeconomic ones (if not more!) in enhancing national economic prosperity.

Mankiw, Romer, and Weil (1992) argue that the level of economic development depends upon the accumulation of physical and human capital. Hence, it is possible to predict a positive relationship between investment (as a share of output) and the level of economic development, as well as enrollment in secondary education and the level of economic development. Trade openness is positively associated with economic prosperity (Yannikaya, 2003). International trade would enhance global competition and increase productivity under certain assumptions.

As for latitude, it is expected to have a positive impact on economic prosperity; countries that are far from equator are more likely to have a higher level of eco- 
Table 1

Description of Dependent and Independent Variables

\begin{tabular}{|c|c|c|c|c|}
\hline & Variable & Description & Year-Period & Source \\
\hline GDPC & $\begin{array}{l}\text { Gross Domestic Product per capita, } \\
\text { PPP adjusted (Current International } \\
\text { Dollars) }\end{array}$ & $\begin{array}{l}\text { GDP per capita (PPP adjusted) is the gross } \\
\text { domestic product divided by midyear } \\
\text { population converted to international dollars } \\
\text { using purchasing power parity rates. An } \\
\text { international dollar has the same purchasing } \\
\text { power over GDP as the U.S. dollar has in the } \\
\text { United States. Logged values are taken into } \\
\text { consideration. }\end{array}$ & 2006 & $\begin{array}{l}\text { International Monetary Fund } \\
\text { (IMF), World Outlook Database } \\
2007\end{array}$ \\
\hline 1 & Investment as a share of GDP (\%) & $\begin{array}{l}\text { Investment share of current gross domestic } \\
\text { product. }\end{array}$ & $2003-2006$ & Penn World Tables, UN Statistics \\
\hline OPENNESS & Trade Openness as a share of GDP (\%) & $\begin{array}{l}\text { Sum of exports and imports as a share of } \\
\text { GDP. }\end{array}$ & $2003-2006$ & Penn World Tables, UN Statistics \\
\hline EDUCATION & $\begin{array}{l}\text { Gross enrolment rate in secondary } \\
\text { education }(\%)\end{array}$ & $\begin{array}{l}\text { Number of pupils enrolled in secondary, } \\
\text { regardless of age, and expressed as a } \\
\text { percentage of population in the theoretical } \\
\text { age group for secondary education. }\end{array}$ & $2003-2006$ & World Bank, Education Statistics \\
\hline
\end{tabular}


Table 1 cont'd.

Description of Dependent and Independent Variables

Variahle Description Year-Perio

IBS Innovation and Business Sophistication Simple average of the following scores Score

developed by the World Economic Forum

(WEF): (1) business sophistication score, a

composite index which comprises, among

other components, the production process

sophistication, the extent of marketing, the

willingness to delegate authority, the nature

of competitive advantage and the presence

of a value chain; and (2) innovation score,

which covers, among others components,

the degree of company spending on research

and development, the quality of government

procurement of advanced technology

products and the number of utility patents.

This composite indicator varies from 1 (low

level of business sophistication and business

innovation) to 7 (high level of business

sophistication and business innovation).

ETHICS Ethical behavior of firms

Measures the quality of the ethical behavior of a countryís firms in interactions with

World Economic Forum, public officials, politicians, and other enterprises) . It varies from 1 =among the The Global Competitiveness Report, 2005-2006

World Economic Forum,

The Global Competitiveness

Report, 2007-2008 world's worst to $7=$ the best in the world. 
Table 1 cont'd.

Description of Dependent and Independent Variables

\begin{tabular}{|c|c|c|c|c|}
\hline & Variable & Description & Year-Period & Source \\
\hline & Illegal Corruption & $\begin{array}{l}\text { Simple average of the following indices: } \\
\text { (1) Irregular payments in public contracts; } \\
\text { and (2) Irregular payments in judicial } \\
\text { decisions. Such an index assesses the level } \\
\text { of private-public corruption within a country. } \\
\text { It varies from } 1 \text { (corrupt practices are } \\
\text { common) to } 7 \text { (corrupt practices never occur) }\end{array}$ & 2004 & $\begin{array}{l}\text { World Economic Forum } \\
\text { The Global Competitiveness } \\
\text { Report, 2005-2006 }\end{array}$ \\
\hline $\begin{array}{r}\text { DISTANCE FROM } \\
\text { EQUATOR }\end{array}$ & Absolute Latitude & $\begin{array}{l}\text { Absolute Latitude / } 90 \text { measures the distance } \\
\text { from equator. }\end{array}$ & 2006 & \\
\hline & & & & $\begin{array}{l}\text { Meghanna, Demirguc-kunt and } \\
\text { Maksimovic (2006). }\end{array}$ \\
\hline FRACTIONALIZATION & Religious Fractionalization & $\begin{array}{l}\text { Probability that two randomly selected } \\
\text { individuals from the country in question will } \\
\text { not belong to the same religious group. }\end{array}$ & 2003 & Alesina et al. (2003) \\
\hline
\end{tabular}


nomic development. Finally, political economy models suggest that countries with high fractionalization (i.e., ethnic, linguistic, or religious fractionalization) have a lower level of economic development (for a theoretical framework, see Lindner \& Strulik, 2004). Thus, it is expected to have a negative association between religious fractionalization and economic prosperity.

\section{Econometric Analysis}

Table 2 offers the descriptive statistics of all the dependent and independent variables. The sample comprises 107 observations and covers the period from 2003 to 2006. The descriptive statistics offer the mean, the ranges (minimum and maximum), and the standard deviation of each of the cited variables.

Table 2

Descriptive Statistics of All Dependent and Independent Variables

\begin{tabular}{lccccc}
\hline & Range & Minimum & Maximum & Mean & $\begin{array}{c}\text { Std. } \\
\text { Deviation }\end{array}$ \\
\hline Gross Domestic Product (PPP adjusted) & 4.62 & 6.69 & 11.31 & 9.17 & 1.08 \\
Investment (I) & 41.13 & 3.42 & 44.55 & 15.82 & 7.65 \\
Trade Openness (Openness) & 365.84 & 21.58 & 387.42 & 87.43 & 51.37 \\
Gross Enrollment in Secondary & 144.6 & 7.50 & 152.1 & 79.46 & 29.11 \\
$\quad$ Education (EDU) & & & & & \\
Innovation \& Business Sophistication & & & & & \\
$\quad$ (IBS) & 3.15 & 2.62 & 5.77 & 3.85 & 0.81 \\
Ethical Behavior of Firms (Ethics) & 3.50 & 2.80 & 6.30 & 4.29 & 0.88 \\
Illegal Corruption (Ethics) & 4.25 & 2.35 & 6.60 & 4.31 & 1.12 \\
$\begin{array}{l}\text { Innovation \& business sophistication } \\
\quad \text { (IBS) }{ }^{\star} \text { Ethical behavior (Ethics) }\end{array}$ & 26.62 & 7.42 & 34.04 & 17.15 & 7.17 \\
Latitude & & & & & \\
Religious Fractionalization & 0.70 & 0.01 & 0.71 & 0.34 & 0.19 \\
$\quad$ (Fractionalization) & 0.86 & 0.00 & 0.86 & 0.42 & 0.23 \\
\hline
\end{tabular}

Note: Valid sample size is 107 countries.

The cross-nature of the study raises suspicion of heteroskedasticity in the error term that could lead to econometric problems by overestimating the estimated coefficients. Subsequently, the problem of heteroskedasticity is addressed following White's procedure, which gives robust-heteroskedasticity estimates for the variance-covariance matrix of the estimated regression coefficients (1980). The 
multicollinearity test (i.e., the correlation among all pairs of independent variables) shows no serious signs of multicollinearity (Table 3). Additionally, one could not but argue that business innovation and business ethics are endogenous to economic prosperity. However, the lack of valid instruments deters the use of the Two-Stage Least Squares estimation technique, which could have improved the quality of the econometric findings.

Table 4 shows the regression results of the three models previously stated. The coefficients measuring business innovation (i.e., innovation and business sophistication score) and business ethics (i.e., ethical behavior of firms and illegal corruption) are positive, statistically and economically significant at the $99 \%$ level of confidence. They show support for the theoretical frameworks previously elaborated. A one-point improvement (i.e., increase) in each of the 7 points scale stimulates the $\log$ value of level of per capita GDP by $0.47,0.46$, and 0.38 units, respectively, at the $99 \%$ level of confidence. Noteworthy is the equal economic significance of business innovation and business ethics to economic prosperity.

The interaction between innovation and business sophistication and the ethical behavior of firms seems to have a statistically significant impact at the $99 \%$ level of confidence. One possible interpretation of such results is that the deterrence of unethical practices, specifically corrupt practices, within an organization and between an organization and its environment on one hand, and the focus on introducing innovative products and processes on the other one, are essential to sustaining productivity and economic prosperity.

The coefficients of investment and enrollment in secondary education are positive and significant at the $99 \%$ level of confidence. Trade openness loses its significance in models $2(a)$ and 2 (b) when variables measuring business ethics are introduced, despite the absence of any significant correlation between the above variables. Such a result shows that trade openness is not a robust predictor of economic prosperity. The signs of the coefficients of latitude and religious fractionalization are consistent with the expected signs but statistically insignificant.

Both sets of macroeconomic and microeconomic variables seem symbiotic and instrumental to fostering economic prosperity. Interestingly, the standardized estimates of all the independent variables used in the three models show the primacy of microeconomic variables (innovation and business sophistication, ethical behavior of firms, and illegal corruption) over macroeconomic ones (investment and trade openness). 
Table 3

Correlation Matrix Among Independent Variables

\begin{tabular}{|c|c|c|c|c|c|c|c|c|c|}
\hline & $\begin{array}{l}\text { Investment } \\
\text { (I) }\end{array}$ & $\begin{array}{c}\text { E } \\
\text { Trade } \\
\text { Dpenness } \\
\text { (OPENNESS) }\end{array}$ & $\begin{array}{c}\text { Gross } \\
\text { Enrollment } \\
\text { in } \\
\text { Secondary } \\
\text { Education } \\
\text { (EDU) } \\
\end{array}$ & $\begin{array}{l}\text { Innovation } \\
\text { and } \\
\text { Business } \\
\text { Sophisti- } \\
\text { cation } \\
\text { (IBS) } \\
\end{array}$ & $\begin{array}{c}\text { Ethical } \\
\text { Behavior } \\
\text { of Firms } \\
\text { (ETHICS) } \\
\end{array}$ & $\begin{array}{c}\text { Illegal } \\
\text { Corruption } \\
\text { (ETHICS) }\end{array}$ & IBS* Ethics & Latitude & $\begin{array}{l}\text { Religious } \\
\text { Fraction- } \\
\text { alization } \\
\text { (FRACTION- } \\
\text { ALIZATION) } \\
\end{array}$ \\
\hline Investment (I) & 1 & 0.16 & 0.52 & 0.54 & 0.53 & 0.49 & 0.55 & 0.42 & 0.03 \\
\hline Trade Openness (OPENNESS) & 0.16 & 1 & 0.21 & 0.17 & 0.20 & 0.25 & 0.18 & 0.11 & -0.01 \\
\hline Gross Enrollment in Secondary Education (EDU) & 0.52 & 0.21 & 1 & 0.60 & 060 & 0.66 & 0.61 & 0.66 & -0.04 \\
\hline Innovation \& Business Sophistication (IBS) & 0.54 & 0.17 & 0.60 & 1 & 0.89 & 0.80 & 0.97 & 0.43 & 0.11 \\
\hline Ethical Behavior of Firms (ETHICS) & 0.53 & 0.20 & 0.60 & 0.89 & 1 & 0.90 & 0.97 & 0.42 & 0.14 \\
\hline Illegal Corruption (ETHICS) & 0.49 & 0.25 & 0.66 & 0.80 & 0.90 & 1 & 0.86 & 0.48 & 0.11 \\
\hline $\mathrm{IBS}^{*}$ Ethics & 0.55 & 0.18 & 0.61 & 0.97 & 0.97 & 0.86 & 1 & 0.44 & 0.13 \\
\hline Latitude & 0.42 & 0.11 & 0.66 & 0.43 & 0.42 & 0.48 & 0.44 & 1 & -0.04 \\
\hline Religious Fractionalization (FRACTIONALIZATION & N) 0.02 & -0.01 & -0.04 & 0.11 & 0.14 & 0.11 & 0.13 & -0.04 & 1 \\
\hline
\end{tabular}

Note: Valid sample is 107 countries. 
Table 4

Regression Results;

Testing for the Micro-Macro Framework of Economic Development

\begin{tabular}{|c|c|c|c|c|}
\hline & Model 1 & Model 2 (a) & Model 2 (b) & Model 3 \\
\hline Dependent Variable & $\log \operatorname{GDP}_{\mathrm{c} 2006}$ & $\log \operatorname{GDP}_{\mathrm{c} 2006}$ & $\log _{\text {GDP }}{ }_{\mathrm{c} 2006}$ & $\log \operatorname{GDP}_{\mathrm{c} 2006}$ \\
\hline \multicolumn{5}{|l|}{ Independent Variables } \\
\hline Constant & $\begin{array}{l}5.50^{\star \star \star} \\
(0.262)\end{array}$ & $\begin{array}{l}5.432^{\star \star \star} \\
(0.258)\end{array}$ & $\begin{array}{l}5.846^{\star \star \star} \\
(0.205)\end{array}$ & $\begin{array}{l}6.434^{\star \star \star} \\
(0.188)\end{array}$ \\
\hline Investment (I)(\%) & $\begin{array}{c}0.023^{\star \star \star} \\
(0.008) \\
\mathbf{0 . 1 6 3}\end{array}$ & $\begin{array}{c}0.023^{\star \star \star} \\
(0.008) \\
\mathbf{0 . 1 6 5}\end{array}$ & $\begin{array}{c}0.028^{\star \star \star} \\
(0.01) \\
0.200\end{array}$ & $\begin{array}{c}0.022^{\star \star \star} \\
(0.008) \\
0.158\end{array}$ \\
\hline Trade Openness (OPENNESS) (\%) & $\begin{array}{c}0.002^{\star \star} \\
(0.001) \\
\mathbf{0 . 1 0 3}\end{array}$ & $\begin{array}{c}0.002 \\
(0.001) \\
\mathbf{0 . 0 9 0}\end{array}$ & $\begin{array}{c}0.001 \\
(0.001) \\
\mathbf{0 . 0 6 9}\end{array}$ & $\begin{array}{c}0.002 \\
(0.001) \\
\mathbf{0 . 0 9 7}\end{array}$ \\
\hline $\begin{array}{l}\text { Gross Enrollment Rate in Secondary } \\
\text { Education (EDU) }(\%)\end{array}$ & $\begin{array}{c}0.016^{\star \star \star} \\
(0.003) \\
\mathbf{0 . 4 4 1}\end{array}$ & $\begin{array}{c}0.016^{\star \star \star} \\
(0.420) \\
\mathbf{0 . 4 2 0}\end{array}$ & $\begin{array}{c}0.015^{\star \star \star} \\
(0.003) \\
\mathbf{0 . 3 9 2}\end{array}$ & $\begin{array}{c}0.016^{\star \star \star} \\
(0.003) \\
\mathbf{0 . 4 3 3}\end{array}$ \\
\hline $\begin{array}{l}\text { Innovalion and Business } \\
\text { Sophistication (IBS) }\end{array}$ & $\begin{array}{c}0.468^{\star \star \star} \\
(0.084) \\
\mathbf{0 . 3 5 2}\end{array}$ & & & \\
\hline Ethical Behavior of Firms (ETHICS) & & $\begin{array}{c}0.460^{\star \star \star} \\
(0.077) \\
\mathbf{0 . 3 7 7}\end{array}$ & & \\
\hline Illegal Corruption (ETHICS) & & & $\begin{array}{c}0.378^{\star \star \star} \\
(0.062) \\
\mathbf{0 . 3 9 2}\end{array}$ & \\
\hline IBS * ETHICS (Ethical behavior of firms) & & & & $\begin{array}{c}0.055^{\star \star \star} \\
0.010 \\
\mathbf{0 . 3 6 7}\end{array}$ \\
\hline Latitude & $\begin{array}{c}0.336 \\
(0.355) \\
\mathbf{0 . 0 6 0}\end{array}$ & $\begin{array}{c}0.368 \\
(0.348) \\
\mathbf{0 . 0 6 6}\end{array}$ & $\begin{array}{c}0.239 \\
(0.348) \\
\mathbf{0 . 0 4 3}\end{array}$ & $\begin{array}{c}0.301 \\
(0.353) \\
\mathbf{0 . 0 5 4}\end{array}$ \\
\hline Religious Fractionalization & $\begin{array}{l}-0.235 \\
(0.224) \\
-\mathbf{0 . 0 5 0}\end{array}$ & $\begin{array}{c}-0.311 \\
(0.222) \\
\mathbf{- 0 . 0 6 6}\end{array}$ & $\begin{array}{c}-0.282 \\
(0.220) \\
\mathbf{- 0 . 0 6 0}\end{array}$ & $\begin{array}{c}-0.292 \\
(0.225) \\
\mathbf{- 0 . 0 6 2}\end{array}$ \\
\hline Adjusted R-squared & 0.765 & 0.773 & 0.775 & 0.768 \\
\hline Prob. (F-Statistic) & $0.0^{\star \star \star}$ & $0.0^{\star \star \star}$ & $0.0^{\star \star \star}$ & $0.0^{\star \star \star}$ \\
\hline Durbin-Watson Statistic & 1.95 & 1.936 & 2.10 & 1.919 \\
\hline
\end{tabular}

Note: Valid sample size is 107 countries; $p$-values ${ }^{*}<0.1 ;^{* \star}<0.05^{* * \star}{ }^{* *}<0.01$; the dependent variable is economic prosperity measured by the level economic development. Estimates are White robust-heteroskedasticity estimates for the variance-covariance matrix and are reported in the above table. Standard Errors are reported between parentheses. Standardized coefficients are reported in bold. 


\section{Conclusion}

The purpose of this paper is to empirically investigate the effects of business innovation and business/corporate ethics on economic prosperity and their interaction. Additionally, it examines the roles of macro- and microeconomic foundations in fostering national economic prosperity across a sample of 107 countries over the average period from 2003 to 2006. It employs a general macro/microeconomic framework to assess environmental contributions towards productivity and hence economic prosperity.

The econometric results support our hypothesis and show that business innovation and business ethics are significant determinants of economic prosperity. These variables are equally important and interact to sustain economic prosperity. The standardized estimation approach crystallizes the primacy of the microeconomic foundations of economic prosperity over macroeconomic ones.

Accordingly, the sustainability of economic prosperity relies on the capacity of companies to enhance their competitive advantage through innovative products and processes. Effective management of the value chain, decentralization, empowering employees, enhancing research and development are, among others, possible means to enhance the competitive advantage of companies and foster productivity. Effective enforcement of policies and procedures that deter unethical practices (including corrupt practices at the company's level) help reaching a company's objectives and maintain its competitive advantage.

From a policy perspective, the sustainability of the competitive advantage of companies also requires a criminalization of all kinds of unethical private-private and private-public practices. Ratifying the United Nation Convention against Corruption could be one way to reach this objective. Encouraging firms to innovate requires governments, for instance, to enhance the quality of education, enforce the protection of intellectual property rights, simplify and lower the cost of doing business, and promote an entrepreneurial culture via crafting proper tax incentives that can serve such objectives.

To conclude, this study of business innovation and ethics within the prosperity context is a salient issue in a large number of countries that rely heavily on pointsource products, such as several Middle Eastern and North African (MENA) countries, among others. Further research is encouraged to test this micro/macroeconomic framework, coupled with pertinent instrumental variables and a richer longitudinal sample (which is currently not available, especially for the governance variables) that would enable the use of a simultaneous econometric approach on different regions. 


\section{References}

Abramovitz, M. (1994). The origins of the postwar catch-up and convergence boom, in J. Fagerberg, B. Verspagen, \& N. von Tunzelmann (eds). The dynamics of technology, trade and growth. Aldershot, UK: Edward Elgar.

Alesina, A., Devleeschauwer, A., Easterly, W., Kurlat, S., \& Wacziarg, R. (2003). Fractionalization. Working Paper No. 9411. Cambridge, MA: National Bureau of Economic Research.

Bresnahan, T., \& Trajtenberg, M. (1995). General purpose technologies: Engines of growth? Journal of Econometrics, 65, 83-108.

Castellaci, F. (2007). Evolutionary and new growth theories: Are they converging? Journal of Economic Surveys, 21, 585-627.

Chui, M., Levine, P., Murshed, M., \& Pearlman, J. (2002). North-south models of growth and trade. Journal of Economic Surveys, 16(2), 123-165.

Coulomb, R. (1997). Corruption as a corporate threat. Business Ethics, 6, 184-186.

Freeman, C. (1987). Technology policy and economic performance: Lessons from Japan. London: Pinter.

Freeman, C., Clark, J., \& Soete, L. (1982). Unemployment and technical innovation, London: Pinter.

Freeman, C., \& Louca, F. (2002). As time goes by: From the industrial revolutions to the information revolution. Oxford, UK: Oxford University Press.

Grossman, G., \& Helpman, E. (1990). Comparative advantages and long run growth. American Economic Review, 80, 796-815.

Hall, R., \& Jones, C. (1999). Why do some countries produce so much more output per worker than others. The Quarterly Journal of Economics, 114(1), 83-116.

Henisz, W. (2000). The institutional environment for multinational investment. Journal of Law, Economics and Organization, 16, 334-64.

Hellmann, J., \& Schankerman, M. (2000). Intervention, corruption, and capture. Economics of Transition, 8, 545-576.

Helpman, E. (1998). General purpose technologies and economic growth. Cambridge, MA: MIT Press.

Kaufmann, D., \& Kraay, A. (2002). Growth without governance. Policy Research Working Paper No. 2928, Washington: World Bank.

Ketels, C. (2006). Michael Porter's competitiveness framework - Recent learning and new research priorities. Journal of industry, Competition and Trade, 6, 115136. 
Lindner, I., \& Strulik, H. (2004). Why not Africa? Growth and welfare effects of secure property rights. Public Choice, 120, 143-167.

Lucas, R. (1988). On the mechanics of economic development. Journal of Monetary Economics, 22, 3-42.

Mankiw, G., Romer, D., \& Weil, D. (1992). A Contribution to the empirics of economic growth. Quarterly Journal of Economics, 107, 407-437.

Mauro, P. (1995). Corruption and growth. Quarterly Journal of Economics, 110, 681-712.

Meghana, A., Demirguc-Kunt, A., \& Maksimovic, V. (2006). What determines protection of property rights? An analysis of direct and indirect effects. Policy Research Working Paper Series No. 3940. World Bank.

Méon, P., \& Sekkat, K. (2005). Does corruption grease or sand the wheels of growth? Public Choice, 122, 69-97.

Nelson, R., \& Winter, S. (2002). Evolutionary theorizing in economics. Journal of Economic Perspectives, 16(2), 23-46

Perez, C. (1985). Microelectronics, long waves and world structural change: New perspectives for developing countries. World Development, 13(3), 441-463.

Porter, M. (1990). The competitive advantage of nations. New York: Free Press.

Porter, M., Ketels, C., \& Delgado, M. (2007). The microeconomic foundations of prosperity: Findings from the business competitiveness index, in the global competitiveness report: 2007-2008: The World Economic Forum.

Romer, P. (1986). Increasing returns and long-run growth. Journal of Political Economy, 94(5), 1002-1037.

Smarzynska, B., \& Wei, S. (2000). Corruption and composition of foreign direct investment: Firm-level evidence. Working Papers 7969. Cambridge, MA: National Bureau of Economic Research.

Schumpeter, J. (1934). The theory of economic development. Cambridge, MA: Harvard University Press.

Schumpeter, J. (1939). Business cycles. Philadelphia: Porcupine Press.

Schumpeter, J. (1943). Capitalism, socialism and democracy. New York: Harper.

Treisman, D. (2000). The causes of corruption: A cross-national study. Journal of Public Economics, 76, 399-457.

White, H. (1980). A heteroskedasticity-consistent covariance matrix estimator and a direct test for heteroskedasticity. Econometrica, 48, 817-838.

The global competitiveness report: 2007-2008. World Economic Forum. 
The global competitiveness report: 2005-2006. World Economic Forum.

Wu, X. (2005). Corporate governance and corruption: A cross-country analysis. Governance: An International Journal of Policy, Administration, and Institutions, 18, 151-170.

Yannakaya, H. (2003). Trade openness and economic growth: A cross-country empirical investigation. Journal of Development Economics, 72, 57-89.

\section{Biographical Sketch of Authors}

Dr. Rock-Antoine Mehanna is the Dean of the Faculty of Business Administration and Finance at La Sagesse University. He is a Full Professor; Chief Consultant of the Global Strategic Consulting Group; Vice President of the Southwest Academy of International Business (USA); and Vice President for the Mediterranean Region of the Academy for Global Business Advancement (USA). He has previously taught at major universities in the United States, where he has received his graduate studies and professional training. He holds a Ph.D. in Business Policy and an MBA in Finance. He has published several books and a large number of articles in international refereed journals. He has received a large number of international awards, including the most recent "Best Economic \& Business Researcher in the Middle East."

Mr. Youssef Yazbeck is a Financial Analyst in the Banking Control Commission at the Central Bank of Lebanon. He holds a M.S. in Economic Sciences and a B.S. in Economics from the Saint Joseph University. He has researched in the fields of economic development, political economy, economics of competition, among other topics. He has worked as a graduate assistant for Dr. Mehanna on several major research projects. 
